Forthcoming in the China Economic Review

\title{
What is China's True Unemployment Rate?*
}

\author{
John GILES \\ Department of Economics, Michigan State University \\ Albert PARK \\ Department of Economics, University of Michigan \\ Juwei ZHANG \\ Institute of Population and Labor Economics, Chinese Academy of Social Sciences
}

October 2004

\begin{abstract}
Using data from a unique survey conducted in five large Chinese cities that employed an internationally comparable definition of unemployment, we find that the unemployment rate of urban permanent residents was 14.0 percent in 2002. Comparing unemployment rate estimates across time and space using data from the 2001 China Urban Labor Survey and China's 2000 population census, we estimate that for China as a whole, from January 1996 to September 2002 the unemployment rate of urban permanent residents increased from 6.1 percent to 11.1 percent, and that of all urban residents, including temporary residents (e.g., migrants), increased from 4.0 to 7.3 percent.

JEL codes: J64, O53, P20

Key words: unemployment, labor, measurement, China

*Corresponding author: Albert Park, Department of Economics, University of Michigan, Ann Arbor, MI 48109-1220, alpark@umich.edu, tel: 734-764-2363, fax: 734-764-2769. The authors acknowledge financial support from the Chinese Academy of Social Sciences, Michigan State University, the Population Studies Center, University of Michigan, International Center for the Study of East Asian Development (Japan), and the World Bank. We thank George Zhong-ze Li for able research assistance.
\end{abstract}




\section{What is China's True Unemployment Rate?}

\section{Introduction}

The late 1990s saw the breaking of China's "iron rice bowl" of guaranteed lifetime employment for state-sector workers in urban areas. Until then, China's gradualist reform policy had emphasized greater competition and managerial incentive reforms to improve the performance of publicly owned enterprises, but had refrained from privatizating or downsizing state-owned enterprises or allowing managers to fire urban workers. In fact, well into the late 1990s, many municipal governments continued to help place new graduates in government or state-sector jobs. Thus, before the late 1990s, accurate unemployment rate measurement was unnecessary because the magnitude of unemployment was too inconsequential to be a policy concern.

By the mid-1990s, China's government leaders realized that the soaring losses of state-owned enterprises were not financially sustainable. The government moved forward with long-delayed plans to diversify ownership of state-owned enterprises and to allow inefficient firms to reduce employment or go bankrupt. Aggressive economic restructuring led to the layoffs of 45 million workers from 1995 to 2002, including 36 million from the state sector (Table 1). The number of state sector workers fell from a peak of 113 million in 1995 to 71 million in 2002 (Table 1). There was an even larger percentage reduction in urban collective sector workers.

As a result of these changes, urban unemployment and urban poverty arose as major policy concerns for the first time since China began its economic reforms, and were highlighted in Wen Jiabao's first speech as China's new premier (People's Daily, March 18, 2003). Now, as in many other countries, employment and unemployment 
have become prominent political issues in China, and China's unemployment rate has become a statistic of intense interest both inside and outside of the country. In the coming years, the unemployment situation will be carefully watched as China continues an ambitious reform agenda to reform and modernize her enterprises, liberalize trade in accordance with her WTO commitments, shift to more indirect mechanisms of managing the macroeconomy, develop a more open, integrated labor market, and put in place an effective social insurance system.

Unfortunately, China's labor statistics have not kept pace with these recent changes. Official statistics count as unemployed only those individuals who register for unemployment benefits with local governments, and are not based on representative sample surveys. Not surprisingly, the official, or registered, unemployment rate is widely believed to significantly understate the true unemployment rate. During the second half of the 1990s, the official (registered) unemployment rate ranged between 2.9 and 3.1 percent, before rising in 2001 and 2002 to reach 4.0 percent (Table 1). These figures overlook millions of workers who were laid off with no expectation of reemployment, who lost jobs but did not register with local governments, and who involuntarily retired early, among others (Solinger, 2001).

Although officially reported unemployment rates are undoubtedly low, none of the alternative estimates of China's unemployment rate are calculated in a way that is consistent with standard international practice, making it difficult to be confident in their accuracy. ${ }^{1}$ Most alternative estimates are calculated based on published government data on employment, registered unemployment, and officially laid off (or xiagang) workers.

\footnotetext{
${ }^{1}$ For alternative estimates of China's unemployment rate, see Appleton et al. (2002), Solinger (2001), Xue and Zhong (2003), and Knight and Xue (2004). The estimates from these sources are summarized in Table 2.
} 
Given that the unemployed in principle should include all jobless individuals who are able to work and searching for work, estimates based on administrative data are subject to two potentially serious shortcomings. First, substantial numbers of officially laid off or registered unemployed workers may actually be working part- or full-time or may no longer be looking for work (i.e., out of the labor force). Second, official numbers by definition exclude the large numbers of unemployed without official status as such.

As seen in Table 2, there is a wide range of alternative estimates, even for the same year. In 1997, for example, estimates of the unemployment rate ranged from 5 to 14 percent. There are also differences in the estimates of trends over time. Knight and Xue (2004) is the only study that reports estimates based on official data spanning the period 1996 to 2002; they find that the unemployment rate based on adjusted official data increased from 4.9 percent in 1996 to 7.1 percent in 1999, falling after 2000 to 6.6 percent in 2001 and 6.2 percent in 2002. In contrast, consistent with our findings, the only other estimates from survey data (for six provinces), also reported in Knight and Xue (2004), showed a steady increase in the unemployment rate from 9.6 percent in 1995 to 11.6 percent in 1999 to 12.4 percent in $2002 .^{2}$

As unemployment becomes a permanent feature of China's market economy, accurate and timely assessments of the unemployment rate will be critical for designing appropriate and timely macroeconomic policies and appropriate social assistance programs. The goal of this paper is to combine information from newly available data sources to provide credible estimates of China's urban unemployment rate. First, we draw upon sample survey data from a 2002 follow-up survey to the China Urban Labor

\footnotetext{
${ }^{2}$ Even these estimates from the China Income Project data employ a nonstandard definition of unemployment, adding up four types of workers: officially registered unemployed, young job-waiters, laidoff unemployed, and premature retirees.
} 
Survey (CULS), which included internationally comparable questions about unemployment. The CULS, conducted in 2001, also asked about employment and nonworking spells since January 1996. Both surveys were directed by the authors and others in five large Chinese cities. To make broader inferences, we compare the unemployment rate estimates from the 2002 follow-up to unemployment patterns over time as measured by the CULS, and to unemployment rate estimates across regions from China's 2000 population census. By making explicit assumptions, we discuss the likely range of China's true rate of unemployment in recent years.

\section{Measuring Unemployment}

An individual is defined to be unemployed if he or she is not working, able to work, and looking for work during defined reference periods. Although conceptually straightforward, many difficult choices must be made in actual measurement. First, reference periods for work and job search activity must be selected. Standard international practice is to ask respondents about work activity during the past week and search activity during the past month (Table 3). Second, there can be ambiguity in defining what constitutes job search, which affects whether an individual is categorized as unemployed or out of the labor force. The unemployment rate also depends on the treatment of temporarily laid off workers, unpaid family workers, and full-time students looking for work; the inclusion of military personnel or the institutionalized population; the age range of the population surveyed; and the definition of availability. The International Labor Organization (ILO) provides recommendations on how to address some of these issues but leaves substantial discretion to individual countries. The 
recommendations are the result of meetings of experts, labor statisticians, and delegates from national governments, employer's organizations, and labor unions.

Most countries follow most but not all of the ILO guidelines. In Table 3, we summarize the ILO standards, along with relevant concepts for how unemployment is defined and measured in the U.S., Canada, Europe, and in the 2002 follow-up to the China Urban Labor Survey. There are quite a few differences across countries, which undoubtedly lead to differences in measured unemployment rates. For example, the Canadian definition of unemployment employs a broader definition of job search and produces unemployment rates that are about one percent greater than they would be using the U.S. definition (Sorrentino, 2000). ${ }^{3}$

The CULS follow-up survey closely follows international practice in defining unemployment. Working individuals are those who engaged in any income-earning work activity during the past week for at least one hour and who actively looked for work in the past month. Work can include a job or business as part of an employer-employee relationship (i.e., paid work), or self-employment. Given the wording of the survey question (Q1 in Appendix 1), unpaid family workers are likely to be reported as not working or unemployed, similar to the U.S. definition and unlike the Canadian definition. If workers had a job but didn't work temporarily for personal reasons such as illness, vacation, a labor dispute, or family responsibilities, they are counted as employed (same as the Canadian definition and very similar to the U.S. definition). Unemployment is meant to reflect unutilized productive capacity in the economy, and so includes those

\footnotetext{
${ }^{3}$ Other aspects of the U.S. unemployment definition are likely to lead to higher unemployment rates than the Canadian definition (e.g., categorization of full-time students looking for work as unemployed and unpaid family workers as possibly unemployed). This suggests that measured unemployment is more sensitive to the definition of job search than these other factors.
} 
who were without work and available for work. The unemployed also include those on temporary layoff who were available for work and expected to be recalled at a definite time within 6 months (consistent with the U.S. definition, Canada defines a one-year recall period), or who were available for work and had a new job starting within one month. Figure 2 shows exactly how questions in the CULS follow-up survey map respondents into the three labor status categories of employed, unemployed, and out of the labor force. In the next section, we present the results and examine their sensitivity to different definitional assumptions.

\section{The China Urban Labor Survey}

The 2001 CULS and its 2002 follow-up survey targeted adults aged 16 and older in a representative sample of urban households in five Chinese cities. The surveys were administered by the Institute of Population and Labor Economics of the Chinese Academy of Social Sciences, working in collaboration with local statistical bureaus. The sample frames for the survey were constructed based on the 2000 census, with lists of urban permanent resident households in sampled communities updated just before the survey in the fall of $2001 .^{4}$ An unemployment questionnaire was included in a 2002 follow-up survey of the same sample. English translations of the unemployment

\footnotetext{
${ }^{4}$ Within each city, a proportional population sampling approach was used to sample an average of 15 households in each of 70 neighborhood clusters. The sampling had three stages. In the first stage jiedao (or neighborhoods) in a city were chosen. All jiedao of the city were listed with their population size, a sampling distance was calculated by dividing the total population of the city by the number of jiedao to be chosen, a starting point was chosen randomly, and each jiedao was selected as a sampling unit based on the sampling distance. Similarly, in stage two juweihui (communities, or residents' committees) were chosen within each jiedao, and in stage three registered urban households were selected using the same procedures but relying on an updated list of urban permanent resident households living in each neighborhood. After a household was selected, all of the family members above age 16 who were no longer in school were interviewed. An average of 10 households were first chosen to be interviewed in each community, and an additional 5 were chosen to be available for interviews if the original households could not be found, had moved, or refused to be interviewed.
} 
questions are provided in Appendix 1. China has a unique resident permit system which assigns permanent residency of individuals to specific communities. This designation can be changed only under specific conditions and are required for many jobs and to get access to local public services such as children's education. Although the CULS included both urban permanent residents and registered temporary residents (i.e., migrants), the sampling of the former is considered more reliable than the sampling of the latter. Also, in some cities, the migrant attrition rate for the 2002 follow-up was very high because many migrants had changed their place of residence. We therefore focus on the unemployment rate of urban permanent residents. This is the most politically salient group to study in any case, since migrants who cannot find jobs often return to their homes. For the 2001 survey, the response rate of urban permanent resident households was 83.5 percent, and the 2002 follow-up successfully found 86.2 percent of the individuals in the 2001 sample. $^{5}$

The CULS was conducted in the cities of Fuzhou, Shanghai, Shenyang, Wuhan, and Xian. These cities were chosen to provide regional diversity and variation in the size of the state versus private sectors. Three of the cities are among China's six largest by population and another ranks tenth. Fuzhou and Shanghai are coastal cities that have enjoyed excellent economic performance throughout the reform period, while Shenyang in the northeast, Wuhan in central China, and Xian in northwest China are interior cities with large, struggling state industrial sectors that have experienced more painful restructuring. When calculating total sample means for the 5 cities, we weight based on the sampling rate in each city.

\footnotetext{
${ }^{5}$ This response rate compares favorably with other large-scale surveys in the U.S. and other developing countries. We are unable to correct for selectivity bias due to non-response, but we do attempt to correct for bias due to attrition.
} 
We first present unemployment rates calculated from data from the 2002 followup survey to the China Urban Labor Survey. Figure 2 presents a flow chart of the questions asked in the CULS follow-up, as well as the number of responses and percentage of responses for possible answers to each question. There are 7147 valid observations, with only 28 responses ( 0.3 percent) dropped because of incompleteness or internally inconsistency.

We report the unemployment rate overall as well as for each city, and for different demographic and education groups (column 1, Table 4). The overall unemployment rate for the 5-city sample in late 2002 was 14.1 percent. The city with the highest rate of unemployment was Wuhan at 21.9 percent, followed by Shenyang (17.7 percent), Xian (15.9 percent), Fuzhou (11.9 percent), and Shanghai (8.8 percent). Women had a higher rate of unemployment than men-16.7 versus 12.0 percent, and middle-aged workers had higher unemployment rates than other age groups.

As noted earlier, unemployment rates can be sensitive to the definition of job search. Of the 583 respondents reporting to be actively searching for work in the past month in question Q10 (Appendix 1), nearly all (579) described the type(s) of job search activity in which they engaged (question Q11). The search activities and percentage of searchers who engaged in each activity are as follows: 1) through work unit or employer, 11.0 percent; 2) through the labor market, employment agency or other referral agency, 47.1 percent; 3) through relatives, friends, or acquaintances, 65.6 percent; 4) through no specific method other than reading advertisements, 15.6 percent; 5) looked for a job while doing other things, 9.7 percent; and 6) other, 6.1 percent. $^{6}$ Of these, the fourth and fifth choices can be classified as passive forms of job search. In all, 7.9 percent of

\footnotetext{
${ }^{6}$ Percentages calculated using sample weights.
} 
searchers engaged only in passive job search. If such individuals are treated as out of the labor force rather than unemployed, the unemployment rate falls by a full percentage point, from 14.1 percent to 13.1 percent. This sensitivity to the definition of job search is very similar to that found in comparing Canadian and U.S. unemployment rate definitions. Riddell (2000) reports that the Canadian unemployment rate would be 0.6 to 0.7 percent lower using the U.S. definition of job search. He argues that passive job searchers more closely resemble active job searchers than non-searchers in their likelihood of working in the future, suggesting that a more inclusive definition of job search is appropriate.

Other differences between the unemployment definition used in the CULS followup and those used in other countries are unlikely to lead to significant differences in estimated unemployment rates. The percentage of urban permanent residents engaged in unpaid family work in China's large cities is very low since self-employment by such residents itself is very uncommon. The six versus twelve month recall period for laid off workers is unlikely to matter, since few laid off workers in China expect to be reemployed at all (only 2.5 percent of laid off workers said they expected to be recalled within 6 months). And only two individuals responded that they were looking for work but not available for work because they were full-time students, suggesting that the treatment of full-time students seeking work is unlikely to appreciably affect measured outcomes.

One potentially important source of bias in the unemployment rate estimates presented in column 1 of Table 4 is attrition bias. The 2002 follow-up to the CULS occurred one year after the CULS, and included 86.2 percent of the original CULS sample. A first test of whether such bias is likely to be important is to compare the 
characteristics of those who were not found in the follow-up with those who were. We found that the lost individuals were slightly younger (45.2 versus 49.0 years of age) and better educated (10.8 versus 10.3 years of schooling). ${ }^{7}$ Lost individuals were slightly less likely to be unemployed in 2001 (11.5 versus 12.6 percent unemployment rates), but the difference was not statistically significant, suggesting that selection effects on unemployment measurement may not be substantial.

To formally control for attrition bias, we employ the inverse probability weighted (IPW) M-estimator which produces consistent estimates given an ignorability assumption that selection can be predicted by observables (Wooldridge, 2002a, 2002b). ${ }^{8}$ We allow the attrition bias to be different in different cities, since many factors (e.g., population mobility, survey administration quality, etc.) across cities are not uniform. Probit models of attrition are estimated for each city, with attrition modeled to be a function of age (through inclusion of age group dummies), sex, years of schooling, household size, number of laborers in the household, and indicator variables for whether the individual was in the work force and whether the individual was unemployed conditional on being in the work force in November 2001. ${ }^{9}$ The inverse of the fitted probabilities are used as weights to recalculate the unemployment rates.

The results after adjusting for attrition are reported in column 2 of Table 4 . The overall unemployment rate falls very slightly, from 14.1 to 14.0 percent, confirming that selection bias is not great. The direction of attrition bias is consistent with the earlier

\footnotetext{
${ }^{7}$ All differences are statistically significantly different than zero at the one percent significance level based on two-sided t-tests allowing for unequal variance within groups. Differences in gender composition, household size, and number of laborers in the household were are not statistically different from zero at the five percent significance level.

${ }^{8}$ Robins, Rotnitzky, and Zhao (1995), first showed how an IPW estimator could be used to estimate conditional means in the presence of attrition in panel data.

${ }^{9}$ In the probit estimation, about 15 percent of observations are dropped because of missing values of regressors. Individuals that do and do not attrit are equally likely to have missing observations.
} 
finding that lost individuals were slightly less likely to be unemployed. The results for different cities and demographic groups also change slightly, but do not alter any of the main unemployment patterns.

CULS Unemployment Rate Estimates, January 1996 to November 2001

The CULS, conducted in late 2001, contained detailed calendar-based work histories that retrospectively documented job changes and transitions to unemployment or retirement. For each non-working spell from January 1996 to the time of the survey, respondents were asked whether they actively searched for work during the spell. If so, they are categorized as unemployed during the entire work spell. The unemployment rates calculated from the responses to these questions are not directly comparable to those calculated from the set of more detailed questions in the CULS follow-up. First, one is defined to be working if one works an average of five hours or more per week in a month, not one hour of work in the last week. Second, the reference period for job search is not specified, and there are no questions about availability for work, or expected return to a job (usually counted as unemployed). We will return to comparability issues later.

For now, we simply present the calculated unemployment rates over time according to the CULS (Table 5). Unemployment rates for different demographic groups are also presented in Figure 3. The overall unemployment rate increased very steadily over time, from 7.2 percent in January 1996, the beginning of the recall period, to 12.7 percent in November 2001, the time of the survey. The absence of cyclicality is striking, and is driven by the large number of workers over age 30 who were laid off during 
restructuring. ${ }^{10}$ In November 2001, the male unemployment rate was 11.1 percent, and the female unemployment rate was 14.9 percent. Unemployment had increased particularly rapidly in Wuhan and Shanghai, among women and the middle-aged, and among less-educated workers.

Our estimates show that the unemployment rate increased steadily over time, even in 2001, when estimates from adjusted official data reported earlier show a decline, corresponding with the phasing out of China's official urban layoff (or xiagang) program. This apparent discrepancy is easily explained by the different calculation methods, highlighting the inadequacy of official data. Because the CULS also asked about official status as laid off or registered unemployed, we are able construct unemployment rate estimates that mirror those based on adjusted official data. We find that while the "true" unemployment rate increased from 11.2 percent in January 2000 to 12.5 percent in January 2001 and 12.7 percent in November 2001, the percent of workers who were registered as unemployed or laid off was 5.1 percent, 6.0 percent, and 5.9 percent at the same three points in time, a trend reversal roughly consistent with estimates using official data. Interestingly, in November 2001 only 31 percent of officially laid off workers and 28 percent of the registered unemployed were actually unemployed using our definition. The balance were either working or out of the labor force. Conversely, as seen in Table 6, the vast majority of the unemployed in November 2001 ( 8.9 percent out of 12.7 percent) had no official status as laid off or registered unemployed. Moreover, the absolute and relative size of the "unofficial" unemployed increased steadily over time, making unemployment rate estimates based on official data increasingly irrelevant for understanding China's true unemployment situation.

\footnotetext{
${ }^{10}$ Unemployment rates for the young (those under 30 ) follow a cyclical pattern as one might expect.
} 


\section{The 2000 Census}

China's 2000 Census included a set of questions that makes it possible to estimate unemployment rates. The relevant questions from the census are provided in Appendix 2. The census first asks whether the respondent worked for at least one hour in an incomeearning activity during the week of October 15-21, 2000. Possible responses are the following: 1) yes; 2) have a job but didn't work because on vacation, training, or work is seasonal; and 3) didn't work for other reasons. If respondents worked, they are asked how many days (1-7). If they didn't work for other reasons, they are asked about the specific reason, with possible choices being that the respondent is a student, does housework, is retired, lost the ability to work, never worked but is looking for work, lost a job and is looking for work, or other. Following standard conventions as much as possible, those choosing the first or second response to the first question are considered employed, and those who report looking for work in the second question are classified as unemployed. The unemployment rate is the number of unemployed divided by the sum of those who are employed or unemployed. Other workers are categorized as out of the labor force.

Using this definition, we calculate the unemployment rate for the nation as a whole, the provinces in which the five sample cities of the CULS reside, and each of the five sample cities (Table 7). We also examine differences by demographic group. For each category, we calculate the unemployment rate for all urban residents as well as separately for urban permanent residents and urban temporary residents (i.e., migrants). Recall that our unemployment rate estimates from the 2001 CULS and the 2002 follow- 
up survey include only urban permanent residents. According to the census, the unemployment rate in urban China at the time of the census was 8.3 percent. The unemployment rate was much higher for urban permanent residents (12.7 percent) than urban temporary residents (4.7 percent).

Another interesting finding from the census results is that for all four CULS cities located in larger provinces (excluded Shanghai is both a city and a province), the unemployment rate of urban residents is higher in the CULS sample cities than in the provinces in which CULS sample cities reside. ${ }^{11}$ Since CULS sample cities are large provincial capitals, this suggests that the unemployment rate among urban residents was greater in larger cities than in smaller cities and towns. Overall, the CULS sample cities have much higher unemployment rates than the urban population of all of China (12.1 percent versus 8.3 percent for all urban workers and 16.0 versus 12.7 percent for urban permanent residents).

\section{Estimating China’s “True” Unemployment Rate}

Our strategy for generalizing our unemployment rate estimates for the CULS five sample cities in 2002 across time and space is to link them to earlier periods using the CULS data and to estimates for other regions using the 2000 census data. This presents two key challenges. The first is timing, since the CULS follow-up survey, the CULS, and the population census occurred at different times, albeit within a 2 -year period. The second is that the questions about unemployment in the three surveys were slightly different. This means that construction of estimates beyond the five-city sample in 2002

\footnotetext{
${ }^{11}$ This is also true for the unemployment rates of urban permanent residents, with the exception of Shenyang, where the provincial unemployment rate is higher (21.3 percent) than the city unemployment rate (19.5 percent).
} 
requires additional assumptions. The resulting estimates therefore should be interpreted cautiously.

First, we attempt to connect our 2002 unemployment rate estimates to the CULS estimates for the same cities for earlier years. Our approach is to use the CULS data on unemployment rates from 1996 to 2001 and aggregate data on provincial employment by sector through 2002 to predict the 2002 unemployment rate in each city using the CULS unemployment definition. We then calculate the difference between this estimate and the more accurate measurement from the 2002 CULS follow-up survey.

We specify forecasting equations in which the unemployment rate in each sector s in city $\mathrm{c}$ in year $\mathrm{t}\left(\mathrm{UR}_{\mathrm{sct}}\right)$ and the city-sector labor force share $\left(\mathrm{LFSH}_{\mathrm{sct}}\right)$ are each a function of a fixed effect (constant), a time trend $\left(\mathrm{YEAR}_{\mathrm{t}}\right)$, and the log of aggregate province-sector employment $\left(\mathrm{PEMP}_{\mathrm{sct}}\right)$ or the province-sector employment share $\left(\mathrm{PEMPSH}_{\mathrm{sct}}\right)$ :

$$
\begin{gathered}
U R_{s c t}=\alpha_{s c}^{0}+\alpha_{s c}^{1} Y E A R_{t}+\alpha_{s c}^{2} \ln \left(P E M P_{s c t}\right)+\varepsilon_{s c t} \\
L_{F S H} H_{s c t}=\beta_{s c}^{0}+\beta_{s c}^{1} Y E A R_{t}+\beta_{s c}^{2} P E M P S H_{s c t}+u_{s c t}
\end{gathered}
$$

This flexible specification allows the relationship between city and provincial outcomes to vary by city-sector. We estimate (1) and (2) using data from 1995 to 2001, and then predict the city-sector unemployment rate and labor force share for 2002 using the estimated coefficients and provincial employment data for $2002 .^{12}$ City unemployment rates are then predicted by taking the average of the predicted city-sector unemployment

\footnotetext{
${ }^{12}$ CULS city-sector unemployment rates and labor force shares for 1996 to 2000 are from December of those years, those for 1995 are from January 1996, and those for 2001 are from November of that year.
} 
rates, weighted by the predicted labor force shares. In Figure 4, we plot actual city yearend unemployment rates from 1995 to 2001 and fitted unemployment rates from 1995 to 2002. The predictions match quite closely the observed patterns in unemployment rates over time.

To compare the 2002 predicted and measured unemployment rates, we use the year-end predictions to estimate the city unemployment rate in the month of the CULS follow-up, assuming the change in the unemployment rate from the previous year occurs evenly over time. The predicted unemployment rates are lower than the measured unemployment rates in all cities except for Shanghai. Taking a weighted average of the differences between actual and predicted unemployment rates for the five cities, we find that the ILO-based CULS follow-up produced unemployment rates that are 1.064 times the predictions based on the CULS unemployment rates. ${ }^{13}$ However, if we exclude Shanghai, the measured unemployment rate is 1.229 times greater than the predicted

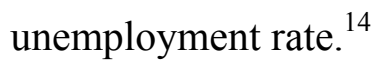

To extend our estimates to other regions, we use the census data to compare unemployment estimates for the 5 CULS sample cities with those of the nation as a whole. From Table 6, we calculate that the census unemployment rate among urban permanent residents throughout China is 79.4 percent of the unemployment rate for the five cities sampled by the CULS, and that the total unemployment rate including migrants

\footnotetext{
${ }^{13}$ Although not strictly necessary for our estimates, we can also estimate the measurement difference between the CULS retrospective measure and the census data. The CULS unemployment rates for October 2000 are 8.7 percent in Shanghai, 14.2 percent in Wuhan, 14.3 percent in Shenyang, 8.5 percent in Fuzhou, and 12.0 percent in Xian. These compare to census estimates for the same month of 14.8 percent (Shanghai), 17.6 percent (Wuhan), 19.5 percent (Shenyang), 14.6 percent (Fuzhou), and 11.1 percent (Xian). Taking a simple average of the percent difference of the census estimates compared to the CULS estimates, we arrive at a "premium" of 38.9 percent. Combined with the earlier bias measure, this suggests that the census data overestimates "true" unemployment by about 30 percent.

${ }^{14}$ The ratios of measured to predicted 2002 unemployment rates by city are as follows: Shanghai 0.855 , Wuhan 1.265, Shenyang 1.150, Fuzhou 1.118, and Xian 1.287.
} 
is 51.9 percent of the unemployment rate of permanent residents in the five-city sample. If we assume that these ratios persist over time, we can adjust the unemployment rate estimates from the CULS follow-up to estimate the "true" unemployment rates for China as a whole. And using our conversion factor for adjusting the CULS retrospective estimates into "true" unemployment rate estimates, we can then construct true unemployment measures for China going back to January 1996.

We display our resulting estimates of China's unemployment rate from January 1996 to September 2002 in Figure 5. The estimated unemployment rate among urban permanent residents increased from 6.1 percent in January 1996 to reach 11.1 percent in September 2002. The unemployment rate of all urban workers including temporary residents increased over the same period from 4.0 percent to 7.3 percent.

\section{International Comparisons}

How does China's unemployment rate compare with other transition economies and other developed and developing countries? In Table 8, we report unemployment rate estimates for different countries for purposes of comparison. Note that as far as we can tell the rates for other countries include both rural and urban populations, while our estimates are for urban China only. In general, rural residents tend to be underemployed rather than unemployed because they often work at least some hours on the farm. For this reason, unemployment often is not a relevant concept for rural workers, making comparisons of urban unemployment rates more meaningful. If rural workers are less likely to be unemployed, we can treat the unemployment rates of other countries as lower 
bound estimates of the urban unemployment rates in those countries. Conversely, China's urban unemployment rates overestimate China's total unemployment rates.

Keeping these caveats in mind, China appears to be an average performer among transition countries even without accounting for the upward bias in China's unemployment rate estimates. She has not reached the peak unemployment rates seen in countries such as Bulgaria, Hungary, Latvia, Lithuania, Poland, Russia, Slovenia, or the Slovak Republic. But her unemployment rates are very close to a number of these countries, and in some years higher than other countries, especially the Czech Republic, Hungary, Lithuania, and the Ukraine. China's urban areas have reached rates of unemployment similar to European countries known for relatively high unemployment (e.g., Italy, Germany, France), and in recent years have exceeded unemployment rates in the UK, USA, and Canada. China's unemployment rate is much higher than other developed countries in Asia, such as Japan and Korea, as well as other developing countries in Asia such as Indonesia and Thailand. Overall, China's unemployment situation is serious, especially in some cities and regions, but does not appear to be high enough to lead to a social or political crisis.

\section{Conclusions}

In this paper, we have calculated estimates of the true rate of unemployment in China by analyzing data from a unique unemployment survey conducted in five large Chinese cities in 2002 that for the first time applied internationally standard definitions of unemployment, and by combining our results with other unemployment measurements across time and space. We calculated an attrition-adjusted unemployment rate of 14.0 
percent in 2002 in our five-city sample, and estimate that the unemployment rate among urban permanent residents throughout China increased from 6.1 percent in January 1996 to 11.1 percent in September 2002. Using a stricter standard for what constitutes job search leads to a reduction in the unemployment rate by one percentage point.

Because of the strong assumptions required to arrive at these estimates, they should be viewed with considerable caution. Nonetheless, we believe that they are the most credible estimates possible given the current state of Chinese labor data. Overall, China's unemployment rate increased substantially during the period of economic restructuring. This experience is typical of transition economies, and even some European nations. The large differences between our estimates and other measurements from surveys that ask simple questions about work status, such as the 2000 census, highlight the importance for China to develop an unemployment monitoring system based on international standards that facilitate meaningful comparisons. We also note that in addition to the rapid increase in unemployment, China also witnessed a rapid reduction in labor force participation during the late 1990s (Giles, Park, and Cai, forthcoming). If many of these individuals are discouraged workers, the unemployment rate could underestimate the actual dislocation experienced by workers in urban China. 


\section{References}

Appleton, S., Knight, J., Song, L., \& Xia, Q., 2002. Labor retrenchment in China: determinants and consequences, China Economic Review 13, 252-275.

Giles, J., Park, A., \& Fang, C., forthcoming. "How has Economic Restructuring Affected Workers in Urban China?," The China Quarterly.

Kernen, Antoine, and Jean-Louis Rocca. 1999. The Reform of State-Owned Enterprises and its Social Consequences in Shenyang and Liaoning, mimeo.

Knight, J., \& Xue, J., 2004. How High is Urban Unemployment in China?, mimeo.

Lee, Hong Yong. 2000. "Xiagang, the Chinese Style of Laying Off Workers," Asian Survey 40(6): 924.

Rawski, Thomas. 2001. "China by the Numbers: How Reform Affected Chinese Economic Statistics," China Perspectives 33: 25-34.

Riddell, W.C., 2000. Measuring unemployment and structural employment, Canadian Public Policy—Analyse de Politiques 26(supplement), S101-S108.

Robins, J.M., Rotnitzky, A., \& Zhao L. P., 1995. Analysis of semiparametric regression models for repeated outcomes in the presence of missing data, Journal of the American Statistical Association 90, 106-121.

Solinger, D., 2001. Why we cannot count the 'Unemployed', China Quarterly 167, 671688.

Sorrentino, C., 2000. International unemployment rates: How comparable are they?" Monthly Labor Review 123, 3-20.

United Nations Development Program. 1999. China Human Development Report 1999: Transition and the State (New York: Oxford University Press).

People's Daily. 2003. Wen on major problems facing new government, People's Daily (English) (http://english.peopledaily.com.cn/200303/18/eng20030318 113493.shtml), March 18th.

Wooldridge, J., 2002. Inverse Probability Weighted M-Estimators for Sample Selection, Attrition, and Stratification, Center for Microdata Methods and Practice Working Paper CWP 11/02.

Wooldridge, J., 2002. Econometric Analysis of Cross Section and Panel Data, MIT Press, Cambridge. 
Xue, J. \& Zhong, W., 2003. Unemployment, poverty and income disparity in urban China, Asian Economic Journal 17, 383-405. 
Figure 1: “Official” Registered Unemployment Rate, 1978 to 2002

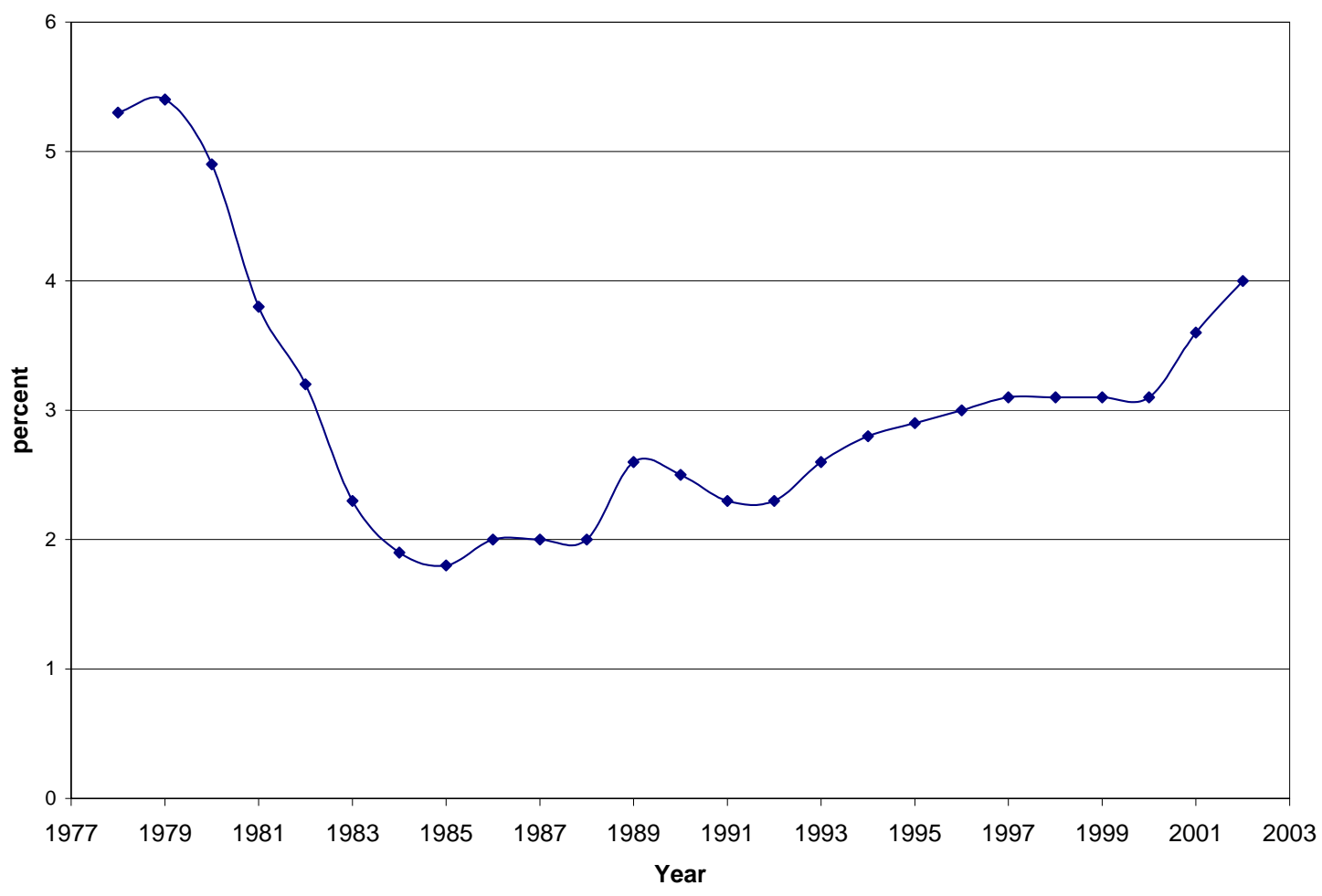


Figure 2

Unemployment Question Flow Chart and Responses

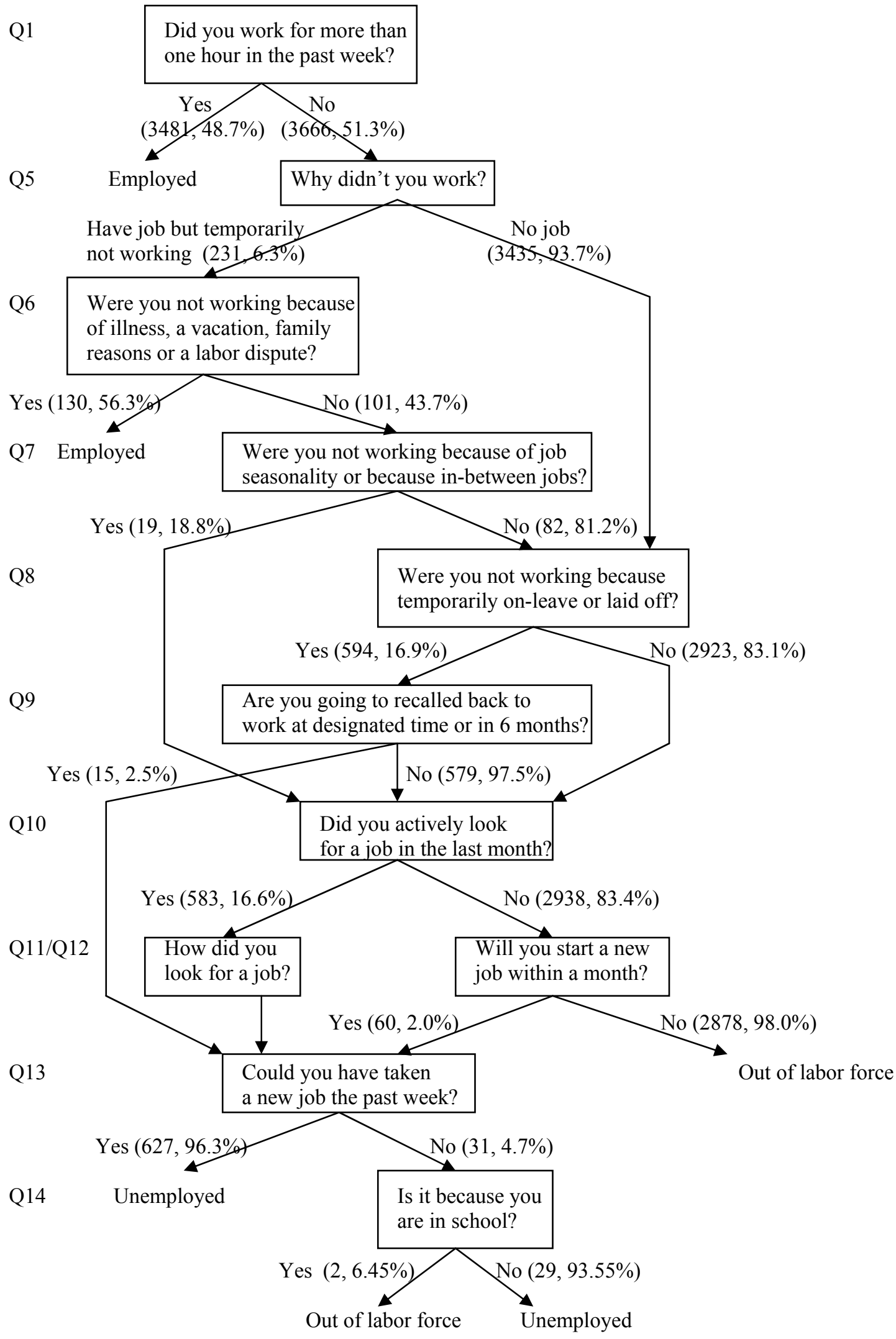


Figure 3

Unemployment Rates
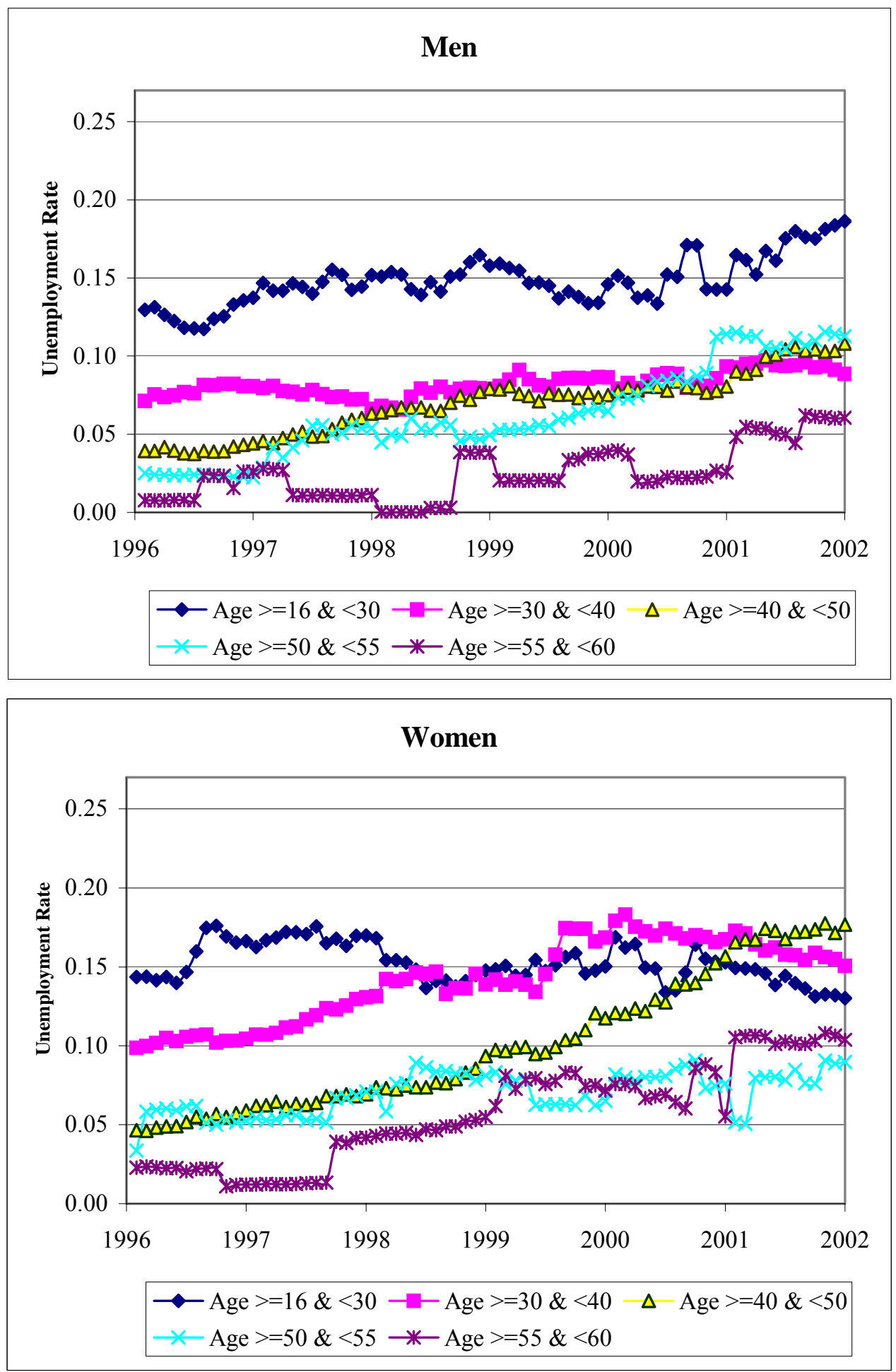

Source: China Urban Labor Survey (Fuzhou, Shanghai, Shenyang, Wuhan, Xian) 
Figure 4: Actual and Predicted Unemployment Rates by City
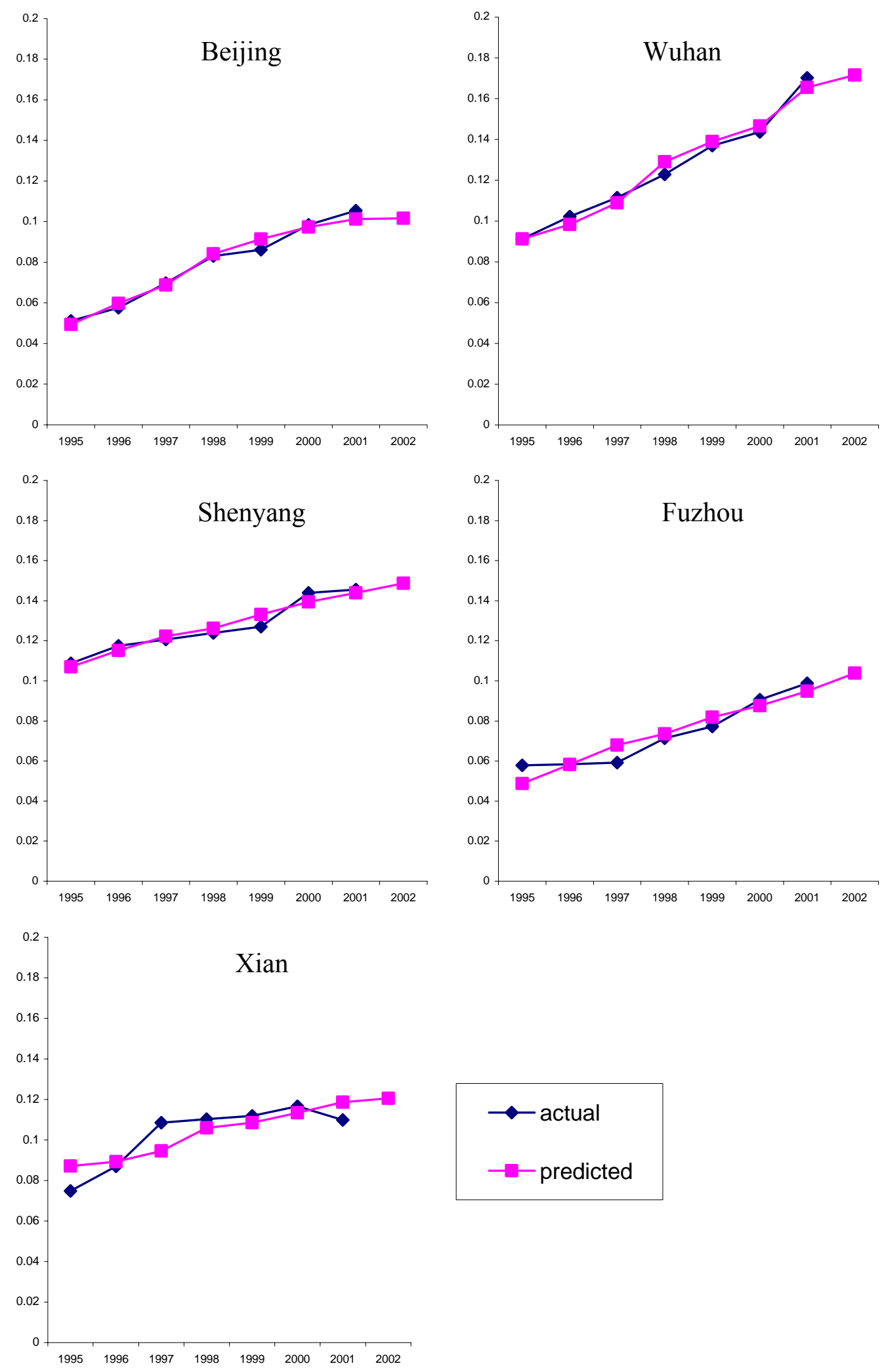
Figure 5

Estimated Chinese Unemployment Rates, 1996 to 2002

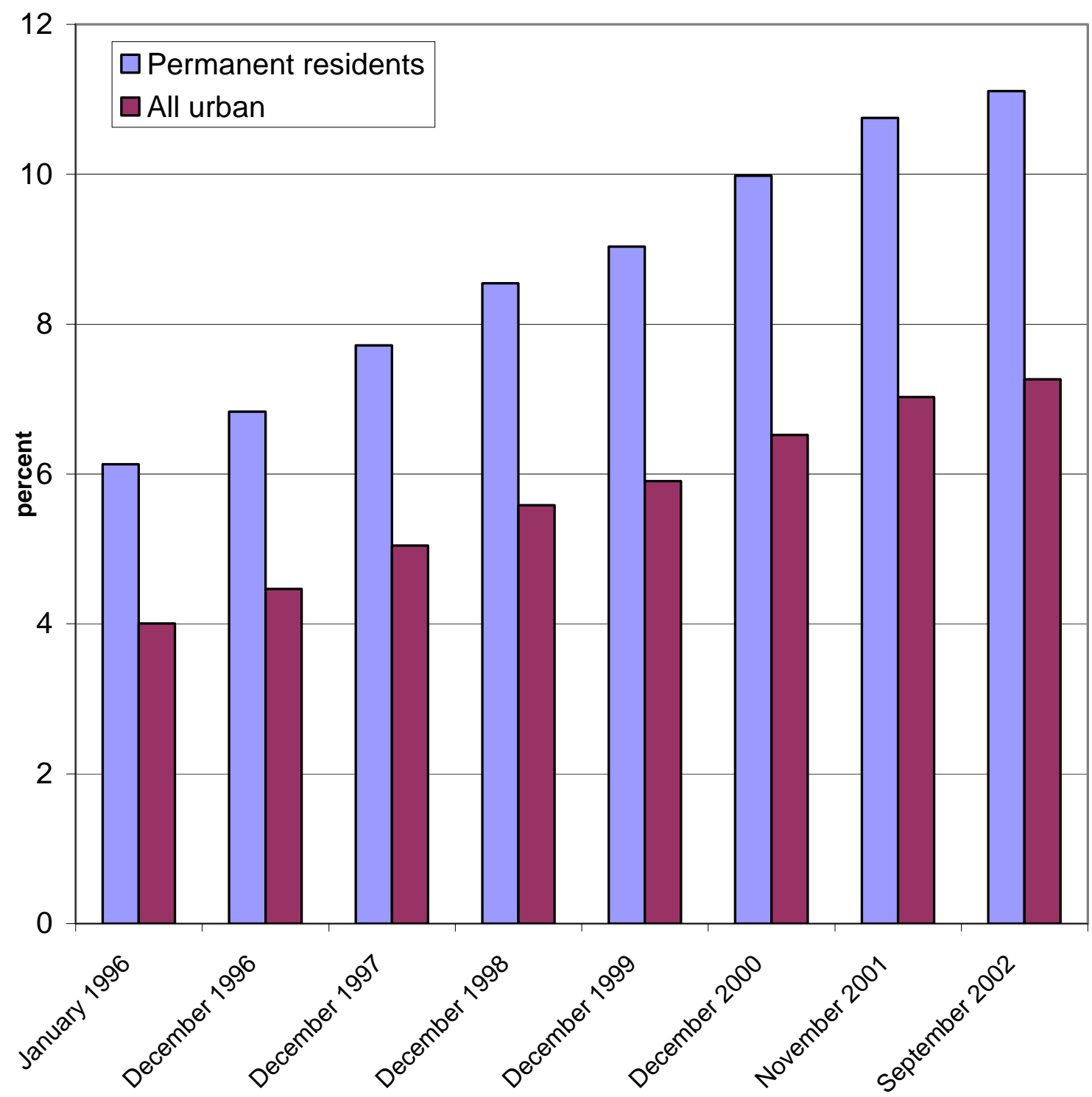


Table 1: Urban Employment Indicators, 1995 to 2002

\begin{tabular}{cccccc}
\hline Year & $\begin{array}{c}\text { Laid off } \\
\text { (xiagang) } \\
\text { workers } \\
\text { (million) }\end{array}$ & $\begin{array}{c}\text { Laid off } \\
\text { (xiagang) SOE } \\
\text { workers } \\
\text { (million) }\end{array}$ & $\begin{array}{c}\text { Number } \\
\text { of SOE } \\
\text { workers } \\
\text { (million) }\end{array}$ & $\begin{array}{c}\text { Registered } \\
\text { unemployed } \\
\text { workers } \\
\text { (million) }\end{array}$ & $\begin{array}{c}\text { Registered } \\
\text { unemployment } \\
\text { rate } \\
\text { (percent) }\end{array}$ \\
\hline 1995 & 5.64 & 3.68 & 112.61 & 5.20 & 2.9 \\
1996 & 8.15 & 5.42 & 112.44 & 5.53 & 3.0 \\
1997 & 6.34 & 6.34 & 110.44 & 5.77 & 3.1 \\
1998 & 7.39 & 5.62 & 90.58 & 5.71 & 3.1 \\
1999 & 7.81 & 6.19 & 85.72 & 5.75 & 3.1 \\
2000 & 5.12 & 4.45 & 81.02 & 5.95 & 3.1 \\
2001 & 2.83 & 2.34 & 76.40 & 6.81 & 3.6 \\
2002 & 2.11 & 1.62 & 71.63 & 7.70 & 4.0 \\
Total & 45.39 & 35.66 & & & \\
\hline Soun & & & & & \\
\hline
\end{tabular}

Source: China Labor Statistical Yearbook, 1996-2002; Annual Report on Labor and Social Security by MOLSS and NSBC 
Table 2

Estimates of China's Unemployment Rate

\begin{tabular}{|c|c|c|c|c|c|c|c|c|c|c|c|}
\hline Source & Method & 1993 & 1994 & 1995 & 1996 & 1997 & 1998 & 1999 & 2000 & 2001 & 2002 \\
\hline XZ\&KX & census/population survey & & & $7.6-7.7$ & & & & & 11.5 & & \\
\hline XZ\&KX & 6 province survey & & & $9.5-9.6$ & & & & 11.6 & & & 12.4 \\
\hline AKX & adjusted official data & & & & & & & 8.2 & & & \\
\hline $\mathrm{XZ}$ & adjusted official data & 3.2 & 3.6 & 4.3 & 4.8 & 5.5 & 4.5 & 6.3 & 8.1 & & \\
\hline KX & adjusted official data & 3.2 & 3.6 & 4.4 & 4.9 & 5.7 & 6.9 & 7.1 & 7.1 & 6.6 & 6.2 \\
\hline $\mathrm{Hu}^{*}$ & adjusted official data & & & & & $5.0-7.0$ & $>8.0$ & & & & \\
\hline $\mathrm{UN}^{*}$ & adjusted official data & & & & & & & $7.9-8.5$ & & & \\
\hline Lee* $^{*}$ & adjusted official data & & & & & & & $8-9$ & & & \\
\hline $\mathrm{KR}^{*}$ & source unclear & & & & & 14.0 & & & & & \\
\hline $\mathrm{XZ}$ & $\begin{array}{l}\text { author's estimates from } \\
(1),(2), \text { and }(4)\end{array}$ & 7.1 & 8.6 & 7.7 & 7.3 & 9.2 & 10.8 & 12.5 & 11.5 & & \\
\hline $\mathrm{KX}$ & $\begin{array}{l}\text { Authors' estimates from } \\
(1),(2) \text {, and (5) }\end{array}$ & 5.9 & 6.8 & 7.7 & 8.5 & 9.5 & 10.1 & 10.8 & 11.5 & 12.6 & 13.1 \\
\hline
\end{tabular}

*cited in Solinger (2001)

$\mathrm{XZ}=$ Xue and Zhong (2003)

$\mathrm{KX}=$ Knight and Xue (2004)

$\mathrm{AKX}=$ Appleton, Knight, Song, and Xia (2002)

$\mathrm{Hu}=\mathrm{Hu}$ Angang, cited by Rawski (2001)

UNDP=United Nations Development Program (1999)

Lee $=$ Lee (2000)

$\mathrm{KR}=$ Kernen and Rocca (1999) 
Table 3: International Unemployment Definitions

\begin{tabular}{|c|c|c|c|c|c|}
\hline & $\begin{array}{l}\text { ILO } \\
\text { Standard }\end{array}$ & U.S. & Canada & Eurostat & China (CULS) \\
\hline Frequency & biannual & monthly & monthly & annual & one-time \\
\hline $\begin{array}{l}\text { Institutional } \\
\text { population }\end{array}$ & included & excluded & excluded & excluded & excluded \\
\hline Age limits & unspecified & $\geq 16$ years & $\geq 15$ years & $\geq 15$ years & $\geq 16$ years \\
\hline $\begin{array}{l}\text { Unpaid family } \\
\text { workers }(<15 \text { hours } \\
\text { per week })\end{array}$ & employed & $\begin{array}{l}\text { not in labor } \\
\text { force/ } \\
\text { unemployed }\end{array}$ & employed & employed & $\begin{array}{l}\text { not in labor } \\
\text { force/ } \\
\text { unemployed }\end{array}$ \\
\hline $\begin{array}{l}\text { Job search reference } \\
\text { period }\end{array}$ & unspecified & 4 weeks & 4 weeks & 4 weeks & 4 weeks \\
\hline Passive search & excluded & excluded & included & included & included \\
\hline $\begin{array}{l}\text { Waiting to start new } \\
\text { job }\end{array}$ & $\begin{array}{l}\text { no search } \\
\text { required }\end{array}$ & search required & $\begin{array}{l}\text { no search } \\
\text { required }\end{array}$ & $\begin{array}{l}\text { no search } \\
\text { required }\end{array}$ & $\begin{array}{l}\text { no search } \\
\text { required }\end{array}$ \\
\hline Temporarily laid off & $\begin{array}{l}\text { search } \\
\text { optional }\end{array}$ & $\begin{array}{l}\text { unemployed if } \\
\text { expecting to be } \\
\text { recalled in } 6 \\
\text { months or recall } \\
\text { date is specified, } \\
\text { no search } \\
\text { required }\end{array}$ & $\begin{array}{l}\text { unemployed } \\
\text { if expecting } \\
\text { to be recalled } \\
\text { within } 1 \text { year, } \\
\text { no search } \\
\text { required }\end{array}$ & $\begin{array}{l}\text { unemployed } \\
\text { only if } \\
\text { searching } \\
\text { for work }\end{array}$ & $\begin{array}{l}\text { unemployed if } \\
\text { expecting to be } \\
\text { recalled in } 6 \\
\text { months or } \\
\text { recall date is } \\
\text { specified, no } \\
\text { search required }\end{array}$ \\
\hline $\begin{array}{l}\text { Full-time students } \\
\text { seeking full-time } \\
\text { work }\end{array}$ & unemployed & unemployed & $\begin{array}{l}\text { not in labor } \\
\text { force }\end{array}$ & unemployed & $\begin{array}{l}\text { not in labor } \\
\text { force }\end{array}$ \\
\hline Availability criterion & unspecified & $\begin{array}{l}\text { during reference } \\
\text { week }\end{array}$ & $\begin{array}{l}\text { during } \\
\text { reference } \\
\text { week }\end{array}$ & $\begin{array}{l}\text { within } 2 \\
\text { weeks of } \\
\text { interview }\end{array}$ & $\begin{array}{l}\text { during } \\
\text { reference week }\end{array}$ \\
\hline $\begin{array}{l}\text { Availability } \\
\text { exceptions }\end{array}$ & unspecified & $\begin{array}{l}\text { temporary } \\
\text { illness, waiting } \\
\text { to start new job }\end{array}$ & $\begin{array}{l}\text { temporary } \\
\text { illness, } \\
\text { personal or } \\
\text { family } \\
\text { responsibiliti } \\
\text { es, awaiting } \\
\text { new job }\end{array}$ & none & $\begin{array}{l}\text { temporary } \\
\text { illness, } \\
\text { personal or } \\
\text { family } \\
\text { responsibilities, } \\
\text { awaiting new } \\
\text { job }\end{array}$ \\
\hline
\end{tabular}

Notes: U.S. concepts are those of the Current Population Survey (CPS) since 1994, Canadian concepts are those of the Labor Force Survey since 1997, and Eurostat concepts are those of the Community Labor Force Survey since 1992.

Source: Concepts for ILO, U.S., Canada, and Eurostat are from official documentation for labor force surveys as compiled by Sorrentino (2000). 
Table 4

Unemployment Rates, September 2002

China Urban Labor Survey (Follow-up)

\begin{tabular}{lcc}
\hline & Unadjusted & Corrected for Attrition Bias \\
\hline Full Sample & 14.1 & 14.0 \\
By City: & & \\
Shanghai & 8.8 & 8.7 \\
Wuhan & 21.9 & 21.7 \\
Shenyang & 17.7 & 17.1 \\
Fuzhou & 11.9 & 11.6 \\
Xian & 15.9 & 15.5 \\
By Demographic Group: & & \\
Men & 12.0 & 11.9 \\
16 to 30 & 11.6 & 11.5 \\
30 to 40 & 14.4 & 14.1 \\
40 to 50 & 13.5 & 13.5 \\
50 to 55 & 8.0 & 8.0 \\
55 to 60 & 8.5 & 8.4 \\
over 60 & 9.3 & 9.3 \\
Women & 16.7 & 16.7 \\
16 to 30 & 13.3 & 13.5 \\
30 to 40 & 17.1 & 16.9 \\
40 to 50 & 19.9 & 19.9 \\
50 to 55 & 16.4 & 16.6 \\
55 to 60 & 10.7 & 10.8 \\
over 60 & 9.4 & 9.7 \\
\hline
\end{tabular}

Note: The sample includes 4267 individuals in the labor force. The adjusted numbers are based on conversion factors calculated from unadjusted and attrition-adjusted means for a sub-sample of 3990 individuals in the labor force with complete data. 
Table 5

China Urban Labor Survey Unemployment Rates, January 1996 and November 2001 (percent)

\begin{tabular}{lccc}
\hline & January 1996 & November 2001 & Change \\
\hline Full Sample & 7.2 & 12.7 & 5.5 \\
By City: & & & \\
Shanghai & 4.9 & 10.4 & 5.5 \\
Wuhan & 9.0 & 17.0 & 8.1 \\
Shenyang & 10.8 & 14.5 & 3.7 \\
Fuzhou & 5.7 & 9.8 & 4.1 \\
Xian & 7.5 & 11.2 & 3.6 \\
By Demographic Group: & & & \\
Men & 6.3 & 11.1 & 4.8 \\
16 to 30 & 13.0 & 18.3 & 5.3 \\
30 to 40 & 6.8 & 9.2 & 2.4 \\
40 to 50 & 4.0 & 10.2 & 6.1 \\
50 to 55 & 2.5 & 11.2 & 5.9 \\
55 to 60 & 0.8 & 5.9 & 5.1 \\
over 60 & 11.2 & 6.7 & -4.5 \\
Women & 8.2 & 14.9 & 6.7 \\
16 to 30 & 14.1 & 13.1 & -1.0 \\
30 to 40 & 10.1 & 15.5 & 5.5 \\
40 to 50 & 4.6 & 17.5 & 12.9 \\
50 to 55 & 3.3 & 9.1 & 5.7 \\
55 to 60 & 2.3 & 11.3 & 9.0 \\
over 60 & 3.6 & 4.0 & 0.4 \\
\hline
\end{tabular}


Table 6

Survey-Based Unemployment Rates Broken Down By Administrative Status

(Unemployment Rates Calculated Using 2001 CULS)

\begin{tabular}{|c|c|c|c|c|c|c|c|}
\hline & Jan-96 & Jan-97 & Jan-98 & Jan-99 & Jan-00 & Jan-01 & Nov-01 \\
\hline Share Unemployed $(1)=(2)+(3)+(4)$ & 0.072 & 0.083 & 0.091 & 0.103 & 0.112 & 0.125 & 0.127 \\
\hline Share Registered as Laid Off (xiagang) (2) & 0.014 & 0.018 & 0.020 & 0.024 & 0.027 & 0.031 & 0.027 \\
\hline Share Registered as Unemployed (3) & 0.003 & 0.004 & 0.005 & 0.008 & 0.009 & 0.012 & 0.011 \\
\hline Share Unemployed and Without Administrative Status (4) & 0.055 & 0.061 & 0.066 & 0.071 & 0.076 & 0.082 & 0.089 \\
\hline
\end{tabular}


Table 7

Unemployment Rates in October 2000, China Population Census

\begin{tabular}{|c|c|c|c|}
\hline & \multicolumn{3}{|c|}{ Urban } \\
\hline & All & Residents & Migrants \\
\hline National & 8.3 & 12.7 & 4.7 \\
\hline Hubei Province (including Wuhan) & 9.6 & 12.9 & 6.7 \\
\hline Liaoning Province (including Shenyang) & 17.0 & 21.3 & 10.3 \\
\hline Fujian Province (including Fuzhou) & 7.3 & 11.4 & 4.3 \\
\hline Shaanxi (including Xian) & 6.1 & 9.2 & 3.7 \\
\hline 5-City Sample & 12.1 & 16.0 & 7.1 \\
\hline \multicolumn{4}{|l|}{ By City: } \\
\hline Shanghai & 11.4 & 14.8 & 7.6 \\
\hline Wuhan & 12.2 & 17.6 & 5.5 \\
\hline Shenyang & 17.5 & 19.5 & 10.8 \\
\hline Fuzhou & 10.2 & 14.6 & 4.8 \\
\hline Xian & 8.4 & 11.4 & 5.2 \\
\hline \multicolumn{4}{|l|}{ By Demographic Group: } \\
\hline Men & 10.7 & 14.9 & 4.8 \\
\hline 16 to 30 & 13.9 & 24.3 & 4.6 \\
\hline 30 to 40 & 9.6 & 14.8 & 3.9 \\
\hline 40 to 50 & 10.5 & 13.0 & 6.1 \\
\hline 50 to 55 & 6.5 & 6.7 & 7.3 \\
\hline 55 to 60 & 6.6 & 8.5 & 6.3 \\
\hline over 60 & 1.1 & 0.7 & 3.8 \\
\hline Women & 14.0 & 17.3 & 10.4 \\
\hline 16 to 30 & 15.1 & 21.4 & 9.2 \\
\hline 30 to 40 & 13.9 & 17.4 & 11.2 \\
\hline 40 to 50 & 14.9 & 16.22 & 15.6 \\
\hline 50 to 55 & 2.4 & 4.51 & 0 \\
\hline 55 to 60 & 1.5 & 4.17 & 0 \\
\hline over 60 & 0 & 0 & 0 \\
\hline
\end{tabular}


Table 8: International Comparison of Unemployment Rates

\begin{tabular}{|c|c|c|c|c|c|c|c|c|c|c|c|c|}
\hline & 199 & & & & & & & & & & & \\
\hline Unemployment rate & 0 & 1991 & 1992 & 1993 & 1994 & 1995 & 1996 & 1997 & 1998 & 1999 & 2000 & 2001 \\
\hline China (urban perm. resid.) & & & & & & 6.1 & 6.8 & 7.7 & 8.5 & 9.0 & 10.0 & 10.8 \\
\hline China (all urban residents) & & & & & & 4.0 & 4.5 & 5.0 & 5.6 & 5.9 & 6.5 & 7.0 \\
\hline Czech Republic (ILO) & & & & & 4.3 & 4.3 & 4.0 & 4.8 & 6.5 & 8.7 & 8.8 & 8.1 \\
\hline Bulgaria (REG) & 1.9 & 7.4 & 13.4 & 15.8 & 14.0 & 11.5 & 10.9 & 14 & 12.2 & 13.7 & 18.2 & 17.5 \\
\hline Estonia (ILO) & 0.7 & 1.5 & 3.7 & 6.6 & 7.6 & 9.7 & 10.0 & 9.7 & 9.9 & 12.3 & 13.7 & 12.7 \\
\hline Hungary (ILO) & & & 9.9 & 12.1 & 11.0 & 10.4 & 10.1 & 8.9 & 8 & 7.1 & 6.5 & 5.8 \\
\hline Latvia (ILO) & & & & 8.7 & 16.7 & 18.1 & 19.4 & 14.8 & 14 & 13.5 & 13.2 & 13.1 \\
\hline Lithuania (REG) & & & & & 3.6 & 6.1 & 7.1 & 5.9 & 6.4 & 8.4 & 11.5 & 12.5 \\
\hline Poland (REG) & 3.4 & 9.0 & 12.9 & 15.0 & 16.5 & 15.2 & 14.3 & 11.5 & 10 & 12 & 14 & 16.2 \\
\hline Slovak Republic (ILO) & & & & 12.8 & 13.7 & 13.2 & 11.1 & 11.8 & 12.5 & 16.2 & 18.6 & 19.2 \\
\hline Slovenia (REG) & & & & 14.4 & 14.5 & 13.9 & 13.9 & 14.4 & 14.5 & 13.6 & 12.2 & 11.6 \\
\hline Ukraine (REG) & & & 0.2 & 0.3 & 0.4 & 0.4 & 1.1 & 1.9 & 3 & 4.1 & 4.3 & 3.9 \\
\hline Russia (ILO) & & & & & & & & 12.8 & 13.4 & 10.8 & 8.9 & 7.6 \\
\hline Spain & 16.3 & 16.4 & 18.4 & 22.7 & 24.2 & 22.9 & 22.2 & 20.8 & 18.8 & 15.9 & 13.9 & 10.5 \\
\hline Italy & 11.0 & 10.9 & 11.4 & $9.8^{2}$ & 10.7 & 11.3 & 11.4 & 11.5 & 11.7 & 11.4 & 10.5 & 9.5 \\
\hline Germany & & 6.6 & 7.9 & 9.5 & 10.3 & 10.1 & 8.8 & 9.8 & 9.7 & 8.8 & 7.9 & 7.9 \\
\hline France & & 9.0 & 10.0 & 11.1 & 12.3 & 11.6 & 12.1 & 12.3 & 11.8 & 11.7 & 10.0 & 8.8 \\
\hline United Kingdom & 6.8 & 8.4 & 9.7 & 10.3 & 9.6 & 8.6 & 8.2 & 7.1 & 6.1 & 6.0 & 5.5 & 4.8 \\
\hline USA & 5.6 & 6.8 & 7.5 & 6.9 & 6.1 & 5.6 & 5.4 & 4.9 & 4.5 & 4.2 & 4.0 & 4.8 \\
\hline Canada & 8.1 & 10.4 & 11.3 & 11.2 & 10.4 & 9.5 & 9.7 & 9.2 & 8.3 & 7.6 & 6.8 & 7.2 \\
\hline Japan & 2.1 & 2.1 & 2.2 & 2.5 & 2.9 & 3.2 & 3.4 & 3.4 & 4.1 & 4.7 & 4.7 & 5.0 \\
\hline Korea & 2.4 & 2.3 & 2.4 & 2.8 & 2.4 & 2.0 & 2.0 & 2.6 & 6.8 & 6.3 & 4.1 & \\
\hline Indonesia & & & & & & & 4.0 & 4.7 & 5.5 & 6.4 & 6.1 & 8.1 \\
\hline Thailand & 2.2 & 2.7 & 1.4 & 1.5 & 1.3 & 1.1 & 1.1 & 0.9 & 3.4 & 3.0 & 2.4 & 2.6 \\
\hline
\end{tabular}

Sources: Unemployment rates for transition economies are from William Davidson Institute. Others are from labor force surveys

based on ILO standards (http://laborsta.ilo.org/). 


\section{Appendix 1: Unemployment Questionnaire, 2002 Follow-up to the China Urban Labor Survey}

Q1 Did you engage in income-earning work for more than one hour in the past week?

1. Yes 2. No $>>$ Q5

Q2 Did you have two or more jobs?

1. Yes 2. No

Q3 How many hours in total did you work in the past week? hour(s)

Q4 What was your income (including bonus and allowance) last week? yuan $>$ end

Q5 Why didn't you work?

1. I have a job but am temporarily not working 2. No job $>>Q 8$

Q6 Were you not working because of illness, a vacation, family reasons or a labor dispute?

1.Yes $>$ end 2. No

Q7 Were you not working because of the seasonality of your employment or because you are inbetween two jobs?

1. Yes $\gg>$ Q10 2. No

Q8 Were you not working because you were temporarily on-leave or laid off?

1. Yes 2. No $>>Q 10$

Q9 Are you going to be called back to work by your work unit at a specific date or will you be able to go back to work within half a year?

1. Yes $\gg>$ Q13 2. No

Q10 Did you actively look for a job in the last month?

1. Yes 2. No $>>$ Q13

Q11 How did you look for a job?

1. Through work unit or employer.

2. Through labor market, employment agency or other referral agency.

3. Through relatives, friends or acquaintances.

4. No specific method but read advertisements.

5. Looked for job when doing other things.

6. Other.

Q12 Could you start a new job within a month?

1. Yes 2. No

Q13 Could you have taken a job that was suitable for you in the past week?

1. Yes $>>$ end 2. No

Q14 Is it because you are in school now? 1. Yes 2. No 


\section{Appendix 2: China 2000 Census Questionnaire}

R17. During the week of October 25-31, did you engage in income earning work for more than one hour?

1. Yes

2. Have job but didn't work because on vacation, training, or work is seasonal $>>R 19$

3. Did not work for other reasons $>>$ R 21

R18. During the week of October 25-31, how many days did you engage in incomeearning work? (1-7)

R21. Reason for not working:

1.Student

2.Housework

3.Retired

4.Lost ability to work

5.Never worked but looking for work

6.Lost job and looking for work

7.Other 